\title{
Organizational Conflict and Job Burnout of Egyptian Hotels Employees
}

\author{
Ahmed Abdelkarim Ghanem
}

Hotel Studies Department, El-Alson Higher Institute for Tourism and Hotels

\begin{tabular}{l}
\hline ARTICLE INFO \\
\hline Keywords: \\
Organizational \\
Conflict; Hotels; \\
Job Burnout. \\
\\
(JAAUTH) \\
Vol. 20, No. 3, \\
(2021), \\
PP. 117-129.
\end{tabular}

\section{ABSTRACT}

The human element in hotels is a key determinant of its success or the opposite, so the hotel management should work to good managing of the organizational conflict in order to reduce job burnout of employee and increase his satisfaction and engagement of work and the resulting increase in its quantity and quality. The study aimed to identify the level of organizational conflict in Egyptian hotels and the degree of job burnout for its employees, and determine the nature of the relationship that links the organizational conflict and job burnout of employees and influence between them. The study found a direct, relationship and a strong influence between organizational conflict and job burnout for Egyptian hotel employees. The study recommended that the management of the hotel should continuously reconsidered the salaries and incentives systems, evaluate performance on periodic, distribution of tasks among employees on the basis of job redesign and including it conforms to the specifications of the individual and the work.

\section{Introduction}

The human factor is one of the most important resources of hotels, indeed it is the main tool in achieving its success and the implementation of its goals, which is considered the main tool to achieve the hotel business progress, it has also multiple influences (سالم ولخضيرى، 2019).

Organizational conflict inside the hotel is one of the most important obstacles to work, as it consumes management's effort and time to confront and solve it instead of investing this time and effort in useful and productive activities, in addition, it has a negative impact on the employee level performance (ميسون إسماعيل، 2017) .

Organizational conflict is an interactive process that appears when there is difference and no agreement between individuals or groups, and when one of the parties interferes in the activities of the other party and prevents him from achieve his goals, or when there is an administrative right for one of the parties to prefer the behavior of one of them over the other while they are doing a shared activity, or when the parties' attitudes, values, beliefs, or skills are differentiated (ليلى قطيشات، 2010). 
The job burnout is the state of psychological imbalance for the worker, which appears as a result of severe psychological pressures that cause work burdens and requirements, which is reflected negatively direct to clients and to the hotel in which the individual works (سماهر مسلم، 2010).

Management should pay close attention with its employees and building their capabilities positively by linking their goals to the goals of the hotel, and working to create an organizational climate that strengthens participation, a sense of responsibility, broadcast a spirit of cooperation and loyalty at work, Therefore, this study comes as an attempt to identify the various factors that affect job burnout and to show the relationship between this burnout and the organizational conflict level in the Egyptian hotels under study as one of the determinants of organizational conflict affecting the degree of job burnout of employees, their motivations to work, and engagement into it.

\section{Study Problem:}

The human element in hotels is a key determinant of its success, so The hole's management should make all the possible efforts to eliminate the organizational conflict that indeed reduce job burnout employee and increase the satisfaction and engagement of work, Therefore, the problem of this study centered in answering the following questions:

1. What is the nature of the organizational conflict in the three-star Egyptian hotels?

2. What is the nature of job burnout of employees in the three -star Egyptian hotels?

3. Is there a relation and effect between the level of the organizational conflict in the Egyptian three -star hotels and job burnout of their employees?

\section{Study Importance:}

The importance of the study is evident in both theoretical and practical standpoint as follows:

1. Utilization of the theoretical framework in identifying the concept of organizational conflict, and job burnout.

2. Utilization of the applied framework in determining the impact of the organizational conflict level in Egyptian three -star hotels on the job employees' burnout.

3. The study helps in setting up many recommendations that aimed at reducing organizational conflict and consequently job burnout with its negative effects.

\section{Study Objectives:}

The study aimed to:

1. Measure the organizational conflict on the Egyptian three -star hotels, and the level of job burnout of their employees.

2. Reveal the nature of the relationship between the organizational conflict on the three -star Egyptian hotels and the job burnout of employees. 
3. Reveal the influence of the organizational conflict in the three -star Egyptian hotels on the job burnout of employees.

4. Reach results that help to put recommendations that will reduce the organizational conflict and job burnout in Egyptian hotels, to benefit those hotels.

\section{Study Hypothesess:}

The study is based on the following two hypotheses:

1. There is a statistically correlation between the organizational conflict in three-star Egyptian hotels and the job burnout of their employees?

2. There is a statistically influence of the organizational conflict in Egyptian threestar hotels on the job burnout of its employees.

\section{Literature Review}

\section{The organizational conflict in hotels}

The hotels became less centralized, and the employees were connected and dependent on each other work, So the visible conflict in hotels has become increasingly. The hotel became less centralized structured, so employees become dependent, and their responsibility for decision making increase (Dumaine, 1991; Nohria, and Garcia-Pont, 1991). These changes led to the emergence of new types of conflicts that can arise between different groups of employees. The workforce became more diverted, among the employees in hotels; women, foreigners, ethnic minorities, people who come from different backgrounds of education and culture. This diversity led to the emergence of different conflict types in the workplace in relation to the period in which the organization had homogeneous workforce (Fiol, 1994; Williamsand O'Reilly,1998).

Conflict is struggle over values and claims to scarce status, power and resources in which the aims of the opponents are to neutralize, insure or eliminate the rivals. Also, it is defined from communication perspective as an expressed struggle between at least two interdependent parties who perceive opposed goals, scarce rewards and interference from other parties in achieving their goals (Hocker and Willmot, 1985).

Many definitions of conflict were found and none of them was unique. Generally, conflict represents a perceived disagreement of interest between persons or groups. According to (Coser, 1996). Also, conflicts inhibit searching for information in the decision-making process (Mitroff and Emshoff ,1979). The conflict was considered as a negative outcome of the cooperative organization system, which led to performance degradation companies (Pondy, 1997).

Blake and Mouton (1984) propose a process of conflict resolution model, confirming previous point of view of the organizational and human conflict. The conflict was defined as irrational clash motivated by interpersonal aggression (Rapoport, 1990).

Conflict is an inevitable part of human activity, hotels encountered external and internal sources of conflict. Within hotels, conflict may vary from small daily divergence at the work to large union clashes. Nonproductive conflict strategies can lead to high stress, high turnover rates that can lastly destroy the overall health of the hotel (Hirschman, 2001; Mckenzie, 2002). 


\section{Burnout in the hotels}

Burnout was defined as emotional exhaustion, ineffectiveness in the workplace and persistent negative responses to stressful conditions of workplace (Moyer et al,2017). Burnout was defined as a syndrome from emotional exhaustion, and feeling ineffective, i.e., a lack of achievement (Maslach et al ,2001).

Burnout results in: decreased productivity, increased absenteeism and high work turnover. Burnout decreases ability to deal with stress and is associated with chronic dysfunction at work, Burnout is considered to be a result of prolonged exposure to chronic stress at work ( Hogarth ,2017).

Babyar (2017) defined burnout as a syndrome composed of three dimensions: feelings of exhaustion, increased cynicism with his job, and a negative perception of his own professional effectiveness. Feelings of exhaustion relate to feelings of being too tired and the exhaustion of employee's emotional and physical resources.

\section{Reasons for Burnout Existence in hotels}

Psychosocial and occupational factors of burnout are divided into internal (employee) and external (work environment) factors, external factors, e.g., poor work organization, insufficient preparation for performing work, low level of organizational support, professional isolation, internal factors include employees feelings about themselves and about their job (Tatalović Vorkapić \& Mustapić, 2012).

The burnout causes are generally divided in two categories: situational factors and individual factors (Bakker et al, 2014). Situational factors include job demands and lack of job resources, job demands are aspects of the job that require sustained effort (Demerouti et al, 2001). Among the most important job demands that cause burnout are role ambiguity, role conflict, stressful events, work overload, and work pressure (Alarcon, 2011; Lee \&Ashforth, 1996).

Therefore, job demands are associated with physiological and psychological costs, e.g., an increased heart rate and fatigue, such symptoms may facilitate the ground of burnout experience, because job demands made employees feeling exhausted and psychologically displaced from work (Bakker et al, 2000).

Physical, psychological, social, and organizational Job resources facilitate the achievement of work goals, reduce job demands and its costs, or encourage personal growth through meaningful work (Bakker \& Demerouti, 2007). The relationship between job resources and burnout is consistently negative, as the lower levels of job resources, the higher levels of burnout, especially when cynicism is concerned (Demerouti et al, 2001).

Bakker, Demerouti, and Euwema (2005) found that when employees felt confident, received feedback, had social support, had a high-quality relationship with their supervisor, subjected to work overload, emotional demands, physical demands, and work-home interference did not result in high burnout levels. Thus, burnout is more likely to develop when high job demands are combined with low job resources. 


\section{Methodology}

Based on the nature of the study and the objectives that seek to achieve, a descriptive and analytical approach that were used. A survey questionnaire was designed based on the studies and references that dealt with the organizational conflict and the job burnout, many modifications have been added or deleted to avoid ambiguity or repetition. It was distributed to (420) staff members of (Housekeeping department) the house keeping department was chosen because it is the most department assigned to it with many tasks that require a lot of effort, and therefore it is more vulnerable to the emergence of the organizational conflict and job burnout, in some three-star hotels in Giza, Cairo Governorate (16 hotels) of which (376) valid forms of analysis were obtained,$(89.5 \%)$ representing the sample of the study.

As the closest to accuracy is choosing three-star hotels because hotels with higher stardom levels (four and five stars) are characterized by stability of management, as they are mostly managed by global management companies, and thus organizational conflict and job burnout rarely arise.

\section{Sample size}

As the size of the total study population is unknown, and the degree of variation is unknown, the following equation was chosen to determine the sample size

$$
n=\left(\frac{z \frac{a}{2}}{2 E}\right)^{2}
$$

$\mathbf{n}=$ sample size

$\mathrm{Z}=$ Standard confidence

$\mathrm{E}=$ error percentage

$\alpha=$ error probability

$\mathrm{N}=385$, so 420 study forms were distributed (Mashaal, 2018)

\section{The questionnaire consisted of:}

1. The organizational conflict scale consists of (13) statement.

2. The job burnout scale consists of (12) statement.

Each of the statements of the first and second axes is given a list of the following statements: Totally Agree (5) - Agree (4) - To some extent (3) - Disagree (2) - Totally Disagree (1), using the Likert scale.

\section{First: Statistical Methods:}

(SPSS.V 20) was used to download, filter and process data as follows:

1. A-Statistical methods used to verify the validity and reliability of the tool:

- Pearson correlation coefficient to ensure the validity of the internal consistency of the questionnaire.

- Alpha Cronbach coefficient for reliability.

2. Statistical methods used to answer study questions.

- The previous Likert scales.

- Frequencies and percentages, in order to reach the arithmetic averages and standard deviations. 
- Pearson correlation coefficient to detect the relationship between variables.

- Simple regression coefficients to determine the effect of the organizational conflict on the job burnout.

\section{Second: The validity and reliability of the study tool:}

\section{Validity of the study tool:}

The correlation coefficient was calculated between each paragraph of the questionnaire and the total score of the scale to which it belongs, The correlation values ranged between $(, 615-, 749)$ and all are at 0.01 , which indicates that the final questionnaire is characterized by a high degree of internal consistency validity, and that all paragraphs will measure what was prepared for measurement.

\section{Reliability of the study tool:}

Alpha (Kronbach coefficient) was used to confirm the reliability of the study tool, The values ranged from (0.720 - 0.840), which are high and higher than 0.7 , which indicates that the questionnaire has a high degree of reliability that meets the requirements applied to the study sample (Zijlmans et al, 2018).

\section{Study Results}

To determine the extent to which the study sample was affected by the organizational conflict, frequencies and percentages were used to reach the arithmetic mean and standard deviations of the responses of the study sample on the organizational conflict scale and total degree as follows:

\section{Table 1}

Organizational conflict scale

\begin{tabular}{|l|l|r|c|}
\hline No & phrases & mean & S. D \\
\hline 1 & $\begin{array}{l}\text { There is tension among employees who have disagreements about } \\
\text { work. }\end{array}$ & 3.58 & 0.78 \\
\hline 2 & There is a mismatch between employees about job tasks. & 3.68 & 0.95 \\
\hline 3 & Employees do not understand each other's views. & 3.65 & 0.86 \\
\hline 4 & Employees hide their discomfort with each other. & 3.58 & 0.78 \\
\hline 5 & $\begin{array}{l}\text { There is a contradiction between the employees in how to perform } \\
\text { the tasks. }\end{array}$ & 3.68 & 0.95 \\
\hline 6 & Personnel powers are not precisely defined. & 3.66 & 0.87 \\
\hline 7 & $\begin{array}{l}\text { There are no specific mechanisms for resolving disputes between } \\
\text { employees. }\end{array}$ & 3.59 & 0.78 \\
\hline 8 & $\begin{array}{l}\text { Interpersonal relationships play a role in disputes over the } \\
\text { performance of work tasks. }\end{array}$ & 3.68 & 0.96 \\
\hline 9 & Each of the conflict parties is only trying to prove his point of view. & 3.65 & 0.86 \\
\hline 10 & Uncontracts are left without quick and correct solutions. & 3.59 & 0.78 \\
\hline 11 & Business disputes are left without quick and correct solutions. & 3.68 & 0.95 \\
\hline 12 & Intellectual differences lead to differences in job performance. & 3.64 & 0.86 \\
\hline 13 & $\begin{array}{l}\text { Conflicts exist among employees due to the centralization of the } \\
\text { decision. }\end{array}$ & 3.66 & 0.88 \\
\hline & & 3.62 & 0.69 \\
\hline
\end{tabular}


It is clear from the results of Table (1) that the members of the study sample respond to the statements of the organizational conflict scale with arithmetic mean ranging between 3,58 and 3,68 These are averages that fall into the fourth category of the Likert scale, which refers to an option "I agree with" in the study tool (survey form), with a standard deviation of 0,78 to 0,95 , This indicates that the members of the study sample experienced high level of the organizational conflict.

\section{Table 2}

Job burnout scale

\begin{tabular}{|l|l|r|r|}
\hline No & phrases & mean & S. D \\
\hline 1 & I feel completely drained at the end of the workday. & 3.57 & 0.78 \\
\hline 2 & $\begin{array}{l}\text { I feel exhausted when I wake up in the morning to face } \\
\text { another workday. }\end{array}$ & 3.59 & 0.82 \\
\hline 3 & I feel emotionally drained by my job. & 3.57 & 0.79 \\
\hline 4 & I feel bored and frustrated with my work. & 3.59 & 0.82 \\
\hline 5 & $\begin{array}{l}\text { Dealing with coworkers directly puts a lot of pressure on } \\
\text { me. }\end{array}$ & 3.57 & 0.78 \\
\hline 6 & $\begin{array}{l}\text { My job duties prevent me from performing my family } \\
\text { duties. }\end{array}$ & 3.59 & 0.83 \\
\hline 7 & I am having difficulty getting time off to rest. & 3.58 & 0.79 \\
\hline 8 & I am unable to attend social events due to workload. & 3.59 & 0.82 \\
\hline 9 & $\begin{array}{l}\text { Sometimes the tasks assigned to me are complicated or } \\
\text { difficult. }\end{array}$ & 3.57 & 0.80 \\
\hline 10 & I became harsh on people since I started this work. & 3.59 & 0.83 \\
\hline 11 & I had to be late at work or do some of my work at home. & 3.57 & 0.79 \\
\hline 12 & I have difficulties with concentration and memory. & 3.60 & 0.82 \\
\hline \multicolumn{2}{|l|}{ Job burnout scale } & 3.56 & 0.670 \\
\hline
\end{tabular}

It is clear from the results of Table (2) that the study sample respondents to the statements of the job burnout scale with mean ranging between 3,57 and 3,60, they are averages that fall into the fourth category of the Likert scale, a category that indicates an option "I agree with" in the study tool (survey form), with a standard deviation of 0,78 to 0,83 , this indicates that there is high level of job burnout among the workers included in the study sample.

And to validate the first hypothesis of the study that there is a correlation of statistical significance between the organizational conflict of hotels and the job burnout, the correlation coefficients were calculated between the total degree of the organizational conflict scale, and the total degree of job burnout as shown in table (3) as follows:

Table 3

Coefficient of correlation between organizational conflict and job burnout

\begin{tabular}{|l|c|}
\hline & the job burnout \\
\hline the organizational conflict & $.747^{* *}$ \\
\hline$* *=0.01$ the correlation coefficient is statistically significant at the level of 0.01
\end{tabular}


Table (3) shows that there is a statistically significant positive correlation at 0.01 degree between the organizational conflict scale and the total degree of the job burnout scale.

To clear the relationship between job burnout as a dependent variable and the organizational conflict as independent variable, the researcher used the simple regression method because of its ability to demonstrate the effect of one independent variable on a dependent variable (second study hypothesis). Simple regression analysis was used at the significance level 001. Table (4) shows the following:

\section{Table 4}

Variance Analysis of independent and dependent variables Correlation and determination coefficients for the regression model

\begin{tabular}{|l|c|c|c|r|}
\hline \multirow{2}{*}{$\begin{array}{l}\text { regression } \\
\text { model }\end{array}$} & Value(F) & $\begin{array}{c}\text { significance } \\
\text { level }\end{array}$ & $\begin{array}{c}\text { Multiple correlation } \\
\text { coefficient }\end{array}$ & $\begin{array}{c}\text { The coefficient } \\
\text { of determination }\end{array}$ \\
\cline { 2 - 5 } & $(1-374)$ d. f & .001 & .747 & .559 \\
\hline
\end{tabular}

Table (4) shows the validity of the model used to test the influence relationship in the value of the job burnout, where the value of $\mathbf{f}$ (473.523) degrees of freedom (1 - 374), The level of significant $(0.001)$ which is less than $(0.05)$, which means that this model with its independent variable is valid to predict the values of the dependent variable.

As for the explanatory power of this model, that shows the percentage change in the dependent variable explained by independent variable, the table shows that the correlation coefficient between the independent variable and the dependent variable was (,747), and the coefficient of determination was (,559), this means that the independent variables explain the $(55.9 \%)$ of the change in the dependent variable (job burnout), and the remaining $(44,1 \%)$ due to other factors.

Table (5)

Simple regression model of the effect of $\mathrm{x}$ (organizational conflict) on $\mathrm{Y}$ (job burnout)

\begin{tabular}{|l|r|r|r|r|r|r|}
\hline variable & $\begin{array}{c}\text { Regression } \\
\text { coefficient } \\
\text { (B) }\end{array}$ & Std & $\begin{array}{c}\text { Std. } \\
\text { error }\end{array}$ & $\begin{array}{c}\text { value } \\
\text { coefficient } \\
\text { Beta }\end{array}$ & $\begin{array}{c}\text { significance } \\
\text { level }\end{array}$ & $\begin{array}{c}\text { Statistical } \\
\text { significance }\end{array}$ \\
\hline (Constant) & .869 & .127 & & 6.841 & .000 & significant \\
\hline $\begin{array}{l}\text { Organizational } \\
\text { conflict }\end{array}$ & .746 & .034 & .747 & 21.761 & .000 & significant \\
\hline
\end{tabular}

Create the regression equation $\mathrm{x}$ over $\mathrm{Y}$ as follows

$\mathrm{Y}=0.869+0.746 \times \mathrm{X}$

Job burnout

Organizational conflict

$$
\begin{array}{ll}
= & \mathrm{Y} \\
= & \mathrm{X}
\end{array}
$$

Table (5) shows that as a result of regression analysis using the method (Enter) between job burnout as a dependent variable and the organizational conflict as independent variable, It was found that were statistically significant according to the 
$\mathrm{T}$ test (at the level of significance, $05 \geq \mathrm{p}$ ), that means organizational conflict have a positive impact on job burnout.

These results are very important for Egyptian hotels as they emphasize the correlation, and the high influence of the level of the organizational conflict on the job burnout of its employees, and the importance of continuous work to reduce these levels, it may cost a lot of money, the spent money will return more in the form of a reduction in absenteeism or leave work, and increasing the effort of the employees, in addition to better quality in their work, and therefore high competition.

\section{Study conclusions and discussions}

The study aimed to measure the level of the organizational conflict on the Egyptian three -star hotels, and the level of job burnout of their employees, revealing the influence, and nature of the relationship between both factors, and through this study, some results were found as follows:

- High level of the organizational conflict on the Egyptian three -star hotels, these results may be due to the interest lack of management of the hotel in defining an accurate job description for each job, that includes duties and responsibilities and developing it with work and employees specifications, these results are agree with the results of Hocker, Willmot (1985), Pondy (1997) and Mckenzie (2002) studies.

- High level of job burnout among the employees included in the study sample, these results may due to interest lack of management of the hotel in moral incentives and Staff Psychological support, and continuous training on the best way to perform their job duties, these results are agree with the results of Bakker, Demerouti, SanzVergel (2014) and Babyar (2017) studies.

- Positive relationship and a strong influence between organizational conflict and job burnout, as the change in the organizational conflict alone without the rest of the variables can change about $(55.9 \%)$ on job burnout, therefore, hotels management should work continuously to eliminate the organizational conflict because of its negative effects on employees represented in job burnout, which leads to a decrease in efficiency and productivity and may ultimately lead to high rates of employees turnover , and as for academics, they should focus on the variables covered by the research and even make them separate teaching courses.

\section{Recommendations}

Based on the results of the study, a set of provided recommendations can be improved the prevailing organizational climate in Egyptian hotels by reducing the organizational conflict and job burnout of employees, so the study recommends the management of hotel to implement the following recommendations:

1. Reconsidering the salaries and incentives systems, evaluating performance on periodic, laying the foundations and rules that guarantee equality for all and work to remove obstacles, whether administrative or financial has Positive repercussions on the individual and performance. 
2. Distribution of tasks among individuals on the basis of job redesign, including it conforms to the specifications of the individual and the work, takes into account fairness and equality in the distribution of burdens on Individuals, where the goal of the redesign is to reduce burdens and enrich the job to increase feeling responsibility, granted powers and independence.

\section{Study limitations}

During the study, the researcher encountered some limitations as follows:

- The limited time allocated to meet members of the study sample (employees) during distributing the questionnaire.

- The large study samples.

- choose of small hotels.

- The interest lack of some members of the sample to answer the questionnaire.

\section{Future studies}

The researcher see that some future researches can be conducted to:

- The relationship between management type and organizational conflict in hotels.

- The relationship between personal variables and organizational conflict in hotels.

- Relationship between organizational climate and job burnout in hotels.

- Relationship between job engagement and job burnout in hotels.

\section{References}

- Alarcon, G. M. (2011). A meta-analysis of burnout with job demands, resources, and attitudes. Journal of Vocational Behavior, 79, pp 549-562.

- Babyar, J. C. (2017). They did not start the fire: reviewing and resolving the issue of physician stress and burnout. Journal of Health organization and Management, 31(4), pp 410-417.

- Bakker, A. B., Demerouti, E., and Sanz-Vergel, A. I. (2014). Burnout and work engagement: The JD-R approach. Annual Review of Organizational Psychology and organizational Behavior, 1, pp 389-411.

- Bakker, A. B., and Demerouti, E. (2007). The Job Demands-Resources model: State of the art. Journal of Managerial Psychology, 22, pp 309-328.

- Bakker, A. B., Demerouti, E., and Euwema, M. C. (2005). Job resources buffer theimpact of job demands on burnout. Journal of Occupational Health Psychology, 10, pp 170-180.

- Bakker, A. B., Schaufeli, W. B., Sixma, H., Bosveld, W., and Van Dierendonck, D. (2000). Patient demands, lack of reciprocity, and burnout: A five-year longitudinal study among general practitioners. Journal of Organizational Behavior, 21, pp $425-441$.

- Blake, R. and Mouton, J. (1984). The Managerial Grid, Houston, TX: Gulf Publishing. 
- Coser, L.A. (1996). The Function Conflict, New York, Routledge and Kogan Paul.

- Demerouti, E., Bakker, A. B., Nachreiner, F., \& Schaufeli, W. B. (2001). The Job Demands-Resources model of burnout. Journal of Applied Psychology, 86, pp 499-512.

- Dumaine, B. (1991). The Bureaucracy Busters, Fortune (June 17th), pp 36 - 50.

- Fiol, C. M. (1994). Consensus, Diversity, and Learning in Organizations, Organization Science, Vol. 5, No. 3, pp 403-420.

- Hirschman, C. (2001), "Order in the Hearing”, HR Magazine, Vol. 46, No.7, pp 58-64.

- Hocker, J.I. and Willmot W.W. (1985) Interpersonal Conflict Dubuque, IOWA: Wmc. Brown Publisher.

- Hogarth, M. (2017). Avoiding burnout. Advances in Library Administration and Organization, 37, pp $71-98$.

- Lee, R. T., and Ashforth, B. E. (1996). A meta-analytic examination of the correlates of the three dimensions of job burnout. Journal of Applied Psychology, 81, pp 123-133.

- Mashaal, A. A. (2018), an analytical study to calculate the optimal sample size in the agricultural survey researchs, the Egyptian Journal of Agricultural Economics, Volume 28, II, p 494.

- Maslach, C., Schaufeli, W. B., and Leiter, M. P. (2001). Job burnout. Annual Review of Psychology, 52, pp 397-422.

- Nohria, N. and Garcia-Pont, C. (1991). Global Strategic Linkages and Industry Structure, Strategic Management Journal, Vol. 12(S1), pp105 - 124.

- Mckenzie, C. (2002). Developing a CCO: conflict-competent organization; Management, Vol. 49, No.2, pp 34-36.

- Mitroff, I. I. and Emshoff, J. R. (1979). On Strategic Assumption-making: A Dialectical Approach to Policy and Planning, Academy of Management Review, Vol. 4, No. 1, pp 1-12.

- Moyer, F., Aziz, S., and Wuensch, K. (2017). From work a holism to burnout: psychological capital as a mediator. International Journal of workplace Health Management, 10(3), pp 213-227.

- Pondy, L. (1997). Organizational Conflict: Concepts and Models; Administrative Science Quarterly, Vol. 12, pp 296-320.

- Rapoport, A. (1990). Fights, Games, and Debates, Ann Arbor: University of Michigan Press

- Tatalović Vorkapić, S., and Mustapić, J. (2012). Internal and external factors in professional burnout of substance abuse counsellors in Croatia. Ann Ist Super Sanità, 48(2), pp 189-197. 
- Williams, K. and O'Reilly, C. (1998). Demography and Diversity in Organizations, In: B. M. Staw and R. M. Sutton (Eds.), Research in Organizational Behavior, Vol. 20, pp 77-140.

- Zijlmans, A. O., Tijmstra, J., Andries van der Ark, L. and Sijtsma, K. (2018). Itemscore reliability in empirical -data sets and its relationship with other item indices, Education and physiological measurement, vol.78 (6), pp998-1020.

- سماهر مسلم عياد، (2010)، ظاهرة الاحتراق الوظيفي لاى الموظفين الإداريين العاملين في وزارة التربية

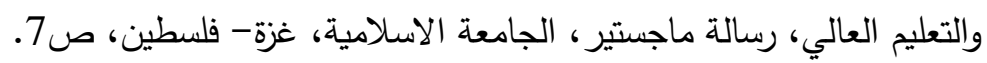
- عمار سالم وأحمد لخضيرى، (2019)، دور تتمية الموارد البشرية في تحقيق الميزة التنافسية، رسالة

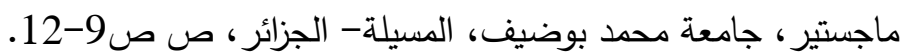

- ليلى قطيشات، (2010)، إدارة الصراع فى المؤسسات التربوية، مركز الكتاب الأكاديمي، ط1، صائ، عمان -

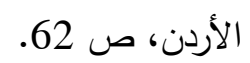

- ميسون إسماعيل محمود الفقعاوى، (2017)، استراتيجيات إدارة الصراع التتظيمي وأثرها على الأداء الوظيفي

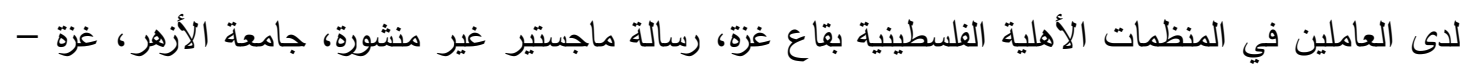

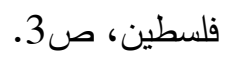




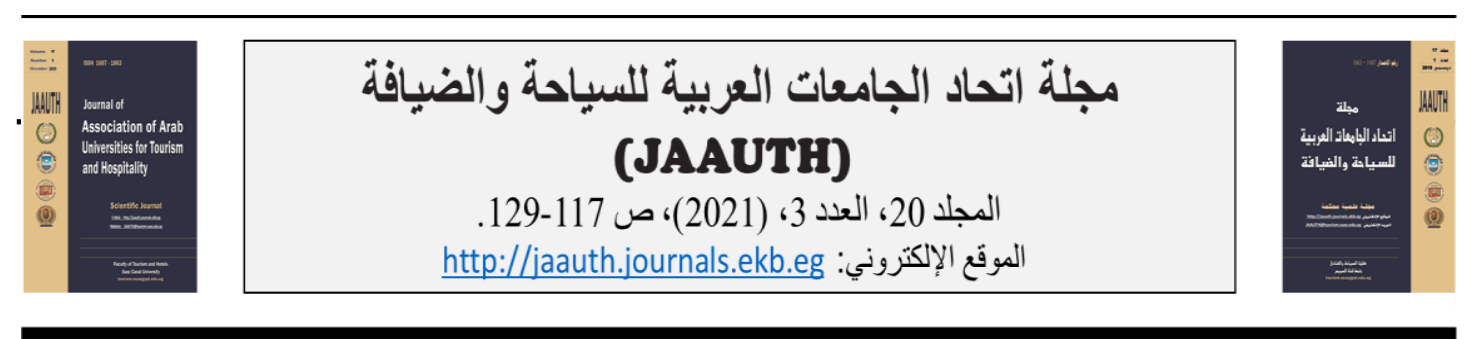

الصراع التنظيمي والاحتراق الوظيفي للعاملين في الفنادق المصرية

أحمد غانم

معهد الألسن العالي للسياحة والفنادق والحاسب الآلي

\begin{tabular}{|c|c|}
\hline الملخص & معلومات المقالة \\
\hline 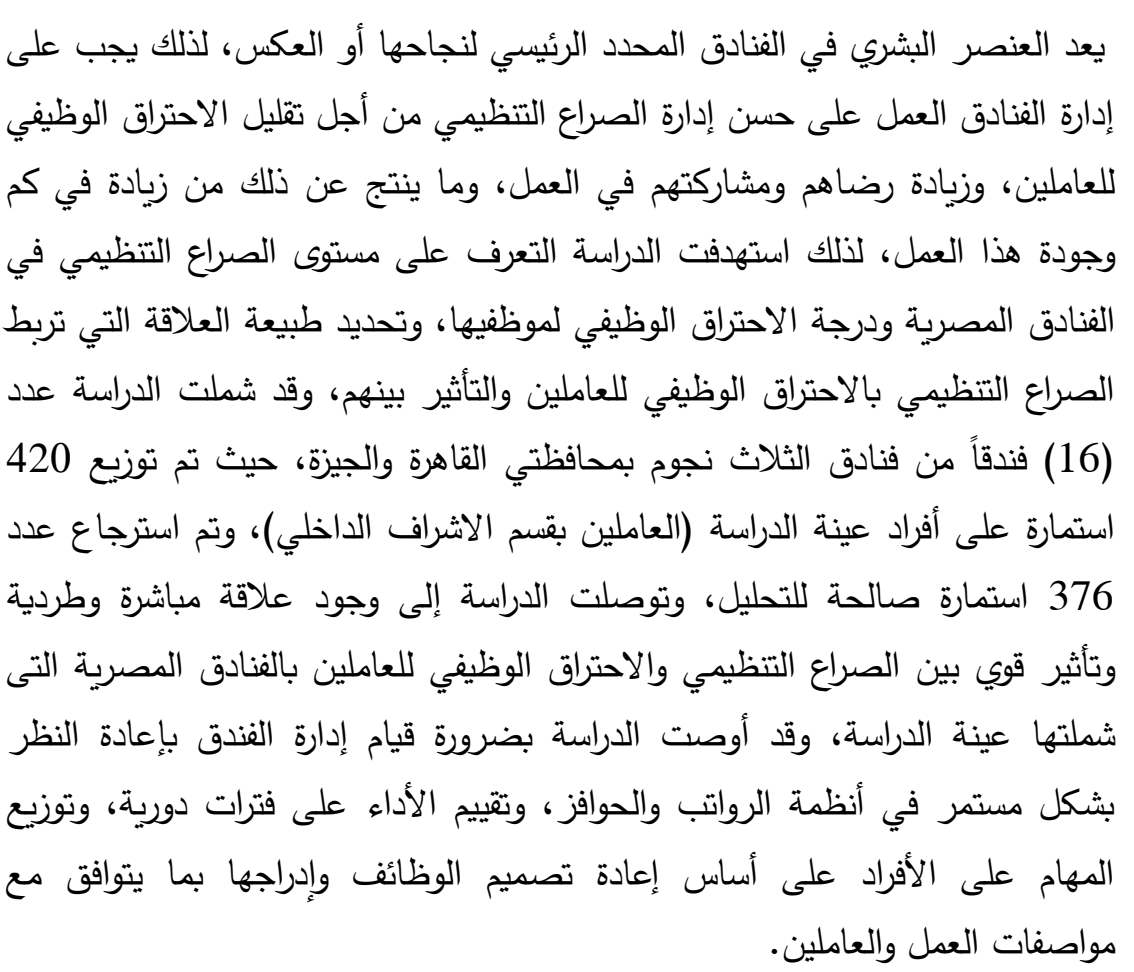 & 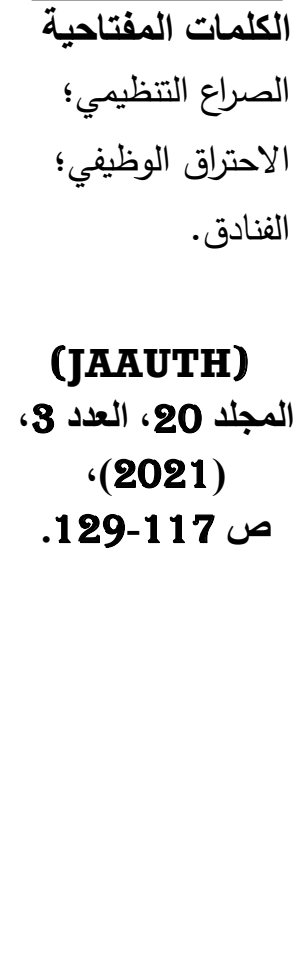 \\
\hline
\end{tabular}

